\title{
FAKTOR-FAKTOR YANG BERHUBUNGAN DENGAN KAPASISTAS KERJA TERHADAP PERILAKU CARING PERAWAT DI RSD BALUNG
}

\author{
Asmuji \\ Fakultas Ilmu Kesehatan Universitas Muhammadiyah Jember \\ asmuji@unmuhjember.ac.id
}

\begin{abstract}
ABSTRACK
Caring is the main element of nursing services that must be given by nurses to all their patients. The application of caring behavior can be influenced by factors related to the work capacity of nurses, such as: gender, age, education level, and work period. This study aims to determine the factors related to the most dominant work capacity towards nurse caring behavior. The study is correlation design. The population is all nurses in Inpatient Room Class III at Balung Hospital were 33 people as research samples. The instrument used is a questionnaire with a likert scale. Ordinal regression statistical test with $\alpha=0.05$ is used as data analysis. ordinal regression test (multinomial regression) is obtained the following results: educational variables with $p$ value $=0.000$; working period variable $p=0.426$; age variable with $p$ value $=0.146$; and sex variables with $p$ value $=.250$. Based on the ordinal regression model, it can be concluded that the influenced variables on the caring behavior variable is the education level variables. Nurse Education is the main factor to improve knowledge and understanding of nurses in caring behavior.
\end{abstract}

Keywords: Work Capacity, Nurse, Caring Behavior

\section{PENDAHULUAN}

Perawat merupakan profesi yang mempunyai peran penting dalam pelayanan kesehatan (Asmuji et al., 2018). Pentingnya peran perawat ditandai dengan intensnya kontak perawat dengan pasien selama 24 jam sehari tanpa berhenti. Bahkan Huber (2006) menyatakan 90\% pelayanan kesehatan di rumah sakit berbentuk pelayanan keperawatan. Asmuji (2016) Krusialnya pelayanan keperawatan, sehingga sangat mempengaruhi mutu pelayanan kesehatan secara keseluruhan.

Ciri khas pelayanan keperawatan dibandingkan dengan pelayanan kesehatan yang lain adalah kepeduliannya (caring) terhadap pasien. Caring menjadi unsur utama pelayanan keperawatan. Perilaku caring ditandai dengan pemberian pelayanan secara ikhlas, totalitas, menghargai, akuntabel (Suarli et al., 2010), penuh perhatian, peduli, rasa hormat, dan sepenuh hati (Chusnawiyah, 2015). Perilaku caring oleh perawat sangatlah penting dalam menciptakan kepuasan klien/pasien. Caring merupakan satu indikator dari berbagai macam indicator mutu pelayanan dirumah sakit. (Prompahakul et al., 2011). 
Kompleksitas caring akan dapat teraplikasi dengan baik jika perawat mempunyai pemahaman yang baik. Perawat yang mampu menerapkan perilaku caring harus mempunyai bekal pengetahuan, sikap, dan psikomotor yang baik pula. Ketiga faktor tersebut di atas mempunyai peranan mempengaruhi kapasistas kerja perawat dalam berperilaku caring. Kapasitas kerja perawat dalam berperilaku caring dapat dipengaruhi pula oleh factor tingkat pendidikan, jenis kelamin, masa kerja, usia, dan pelatihan yang pernah diikuti. Semakin tinggi tingkat pendidikan, semakin lama seseorang bekerja dalam bidangnya, semakin matang usianya, dan semakin sering mengikuti pelatihan maka akan semakin baik pula dalam berperilaku caring.

\section{METODE PENELITIAN}

Desain penelitian ini adalah korelasional dengan pendekatan cross sectional. Populasi penelitian ini adalah seluruh perawat Ruang Rawat Inap Kelas III RSD Balung yang berjumlah 33 orang dan semuanya dijadikan sampel penelitian. Variabel independen penelitian ini adalah factor-faktor yang berhubungan dengan kapasitas kerja perawat (jenis kelamin, usia, tingkat pendidikan, masa kerja), variable dependennya adalah perilaku caring perawat. Instrument yang digunakan adalah kuesioner dengan skala likert. Analisis data menggunakan uji statistic regresi ordinal dengan $\alpha=0,05$.

\section{Hasil Penelitian}

\section{HASIL DAN PEMBAHASAN}

Tabel 1. Distribusi Jenis Kelamin Perawat Ruang Rawat Inap Kelas III RSD Balung Tahun $2018(\mathrm{n}=33)$

\begin{tabular}{lcc}
\hline Jenis Kelamin & Frekuensi & Persentase \\
\hline Laki-laki & 15 & 45,5 \\
Perempuan & 18 & 54,5 \\
\hline Total & 33 & 100 \\
\hline
\end{tabular}

Berdasarkan table 1 di atas dapat diketahui bahwa jumlah responden lakilaki dan perempuan hampir sama. 
Tabel 2. Mean, Median, Modus Usia dan Masa Kerja Perawat Ruang Rawat Inap Kelas III RSD Balung Tahun $2018(n=33)$

\begin{tabular}{lccc}
\hline Variabel & Mean & Median & Modus \\
\hline Usia & 32,8 & 34 & 34 \\
Masa Kerja & 9,5 & 11 & 12 \\
\hline
\end{tabular}

Berdasarkan tabel 2 di atas dapat diketahui rerata usia responden adalah 32,8 tahun, median 34 tahun, dan Modus 34 tahun. Sedangkan rerata masa kerja responden adalah 9,5 tahun, median 11 tahun, dan modusnya adalah 12 tahun.

Tabel 3. Distribusi Tingkat Pendidikan Perawat Ruang Rawat Inap Kelas III RSD Balung Tahun $2018(\mathrm{n}=33)$

\begin{tabular}{lll}
\hline Tingkat Pendidikan & Frekuensi & Persentase \\
\hline DIII Keperawatan & 27 & 82 \\
Ners & 6 & 18 \\
Total & 33 & 100 \\
\hline
\end{tabular}

Berdasarkan tabel 3 di atas menunjukkan bahwa sebagian besar (82\%) responden berpendidikan DIII Keperawatan.

Tabel 4. Distribusi Perilaku Caring Perawat Ruang Rawat Inap Kelas III RSD Balung Tahun $2018(\mathrm{n}=33)$

\begin{tabular}{lll}
\hline Perilaku Caring & Frekuensi & Persentase \\
\hline Tidak caring & 4 & 12 \\
Cukup caring & 20 & 61 \\
Caring & 9 & 27 \\
\hline Total & 33 & 100 \\
\hline
\end{tabular}

Berdasarkan tabel 4 di atas dapat diketahui sebagian besar (61\%) responden mempunyai perilaku caring dalam katagori cukup.

Berdasarkan hasil uji statistik spearmen's rho variabel tingkat pendidikan tidak berhubungan dengan perilaku caring perawat di Ruang Rawat Inap Kelas III RSD Balung (pvalue $=0,461 ; \alpha=0,05 ; \mathrm{r}=0,133$ ). Variabel masa kerja berhubungan dengan perilaku caring perawat di Ruang rawat Inap Kelas III RSD Balung dalam katagori sedang (pvalue $=0,017 ; \alpha=$ $0,05 ; \mathrm{r}=0,411)$. Variabel usia berhubungan dengan perilaku caring perawat di Ruang rawat Inap Kelas III RSD Balung dalam katagori rendah (pvalue= 
$0,058 ; \alpha=0,05 ; r=0,333)$. Variabel jenis kelamin tidak berhubungan dengan perilaku caring perawat di Ruang rawat Inap Kelas III RSD Balung (pvalue= $0,968 ; \alpha=0,05 ; r=0,007)$. Namun jika dilakukan uji regresi ordinal (multinomial regresi) dengan $\alpha=0,05$ antara variabel independen dengan variabel dependen diperoleh hasil sebagai berikut: variabel pendidikan dengan nilai $\mathrm{p}=0,000$; variabel masa kerja nilai $\mathrm{p}=0,426$; variavel usia dengan nilai $\mathrm{p}=0,146$; dan variabel jenis kelamin dengan nilai $\mathrm{p}=0,250$. Berdasarkan model regresi ordinal dapat disimpulkan bahwa variabel yang berpengaruh secara keseluruhan terhadap variabel perilaku caring adalah variabel tingkat pendidikan.

\section{Pembahasan}

a. Tingkat Pendidikan

Pemberian layanan keperawatan bentuknya adalah kinerja perawat. Kinerja perawat diartikan sebagai hasil kerja seorang perawat yang dilakukan sesuai tugas dan tanggungjawabnya dalam organisasi. Kinerja perawat yang menjadi ruh pelayanan keperawatan adalah berupa perilaku caring terhadap pasien yang dilayaninya. Watson (2007) menyampaikan esensi pelayanan keperawatan adalah caring. Caring dalam pelayanan keperawatan berkaitan dengan bagaimana memperlakukan pasien secara manusiawi dan komprehensif sebagai individu yang mempunyai perbedaan dengan individu lainnya.

Sehingga fundamen penting yang harus selalu ditanamkan dalam diri perawat adalah kemampuan tinggi yang mendukung pelaksanaan tugas pemberian layanan keperawatan (Nursalam, 2009). Kemampuan tinggi yang dimaksud akan berkembang dengan baik tentunya harus disokong dengan pemikiran untuk belajar sepanjang hayat. Dengan demikian seorang perawat harus terus meningkatkan pendidikannya, baik secara formal maupun non formal.

Pendidikan menjadi kebutuhan pokok seseorang yang dapat dipergunakan untuk pengembangan dirinya. Pendidikan seorang perawat yang semakin tinggi akan semakin mempermudahkan dalam menerima dan mengembangkan ilmu pengetahuan serta teknologi, sehingga dapat meningkatkan kinerja/produktivitasnya (Groosman, 1999).

Hasil penelitian juga menunjukkan walaupun dari hasil uji statistic Spearmen's rho tidak menunjukkan adanya hubungan antara tingkat pendidikan dengan perilaku caring perawat ( $p$ value $=0,461 ; \alpha=0,05 ; r=0,133$ ), namun berdasarkan model regresi ordinal diperoleh hasil bahwa variabel yang berpengaruh secara keseluruhan terhadap variabel perilaku caring adalah variabel tingkat pendidikan ( $p$ value $=0,000 ; \alpha=0,05$ ).

Hasil penelitian Faizin et al (2008) juga menunjukkan adanya tingkat pendidikan dengan kinerja perawat di Rumah Sakit Umum Pandan Arang Kabupaten Boyolali. Penelitian Kanestren (2009) juga menunjukkan variabel tingkat pendidikan mempunyai hubungan signifikan dengan kinerja perawat. Hal 
ini dapat disimpulkan bahwa perawat yang mempunyai tingkat pendidikan yang lebih baik akan mempunyai kapasitas kerja yang baik pula dalam berperilaku caring.

b. Masa Kerja Perawat

Caring merupakan ruh dari pelayanan keperawatan. Caring dapat menjadi cermin profesionalisme perawat dan menggambarkan kinerja perawat. Dengan demikian caring tidak dapat dilepaskan dari pelaksanaan pemberian asuhan keperawatan. Sebagai inti dari pelayanan keperawatan, caring harus terus ditingkatkan sesuai dengan perkembangan kebutuhan pelayanan keperawatan. Sehingga setiap waktu pelayanan keperawatan, caring dapat terus ditingkatkan aplikasinya. Artinya, semakin lama seorang perawat bekerja dalam pelayanan keperawatan akan semakin baik perilaku caringnya. Hal ini sesuai dengan hasil penelitian yang menunjukkan bahwa masa kerja berhubungan dengan perilaku caring perawat di Ruang rawat Inap Kelas III RSD Balung dalam katagori sedang (pvalue $=0,017 ; \alpha=0,05 ; \mathrm{r}=0,411$ ).

Masa kerja merupakan suatu waktu yang dihitung dari mulainya seorang pegawai/perawat bekerja sampai dengan dilakukannya pengumpulan data penelitian. Masa kerja seringkali menjadi ukuran untuk menentukan kematangan seseorang dalam bekerja. Semakin lama masa kerja seseorang, maka akan semakin matang dalam menguasai pekerjaan yang menjadi keahliannya yang ditunjukkan dengan produktivitas/kinerja yang semakin baik. Kinerja/produktivitas dalam pelayanan keperawatan salah satunya adalah perilaku caring yang ditunjukkan oleh perawat. Beberapa hasil penelitian menunjukkan adanya hubungan antara masa kerja dengan kinerja, antara lain penelitian Elia et al (2016) ada hubungan antara masa kerja dengan produktivitas kerja. Penelitian Faizin et al (2008) bahwa lama kerja perawat berhubungan dengan kinerja perawat di Rumah Sakit Umum Pandan Arang Kabupaten Boyolali. Kanestren (2009), menemukan bahwa variabel lama kerja berhubungan secara bermakna dengan kinerja perawat. Pandaptan (2013) juga menemukan hasil penelitian bahwa masa kerja berpengaruh signifikan terhadap produktivitas kerja karyawan.

Banyak sumber lain juga menyatakan adanya dukungan bahwa masa kerja terkait dengan kinerja seseorang. Sunyoto (2015) menyatakan banyak faktor yang berpengaruh terhadap kinerja seseorang, salah satunya adalah masa kerja. Siagian (2016) juga menyampaikan bahwa lama/masa kerja menjadi faktor yang berkaitan dengan kinerja seseorang termasuk perawat dalam berperilaku caring. Lama kerja seorang perawat akan membuat mereka mendapatkan pengalaman nyata dalam memberikan pelayanan. Sehingga mereka akan mampu menggali sesuatu yang positif di dalamnya untuk terus melakukan yang terbaik. Hal ini akan meningkatkan kapasitasnya dalam berperilaku caring.

c. Usia 
Usia merupakan tahapan yang dilalui individu dalam hidupnya. Selama masa perkembangannya, semakin lama seseorang hidup akan semakin matang, baik secara fisik, mental, dan sosialnya. Namun setelah mencapai masa puncaknya, maka individu secara bertahap juga akan mengalami kemunduran baik secara fisik, mental, dan sosialnya. Perkembangan manusia yang dapat digambarkan seperti grafik lonceng terbalik, maka ini dapat dijadikan acuan kapan manusia mempunyai kapasitas kerja yang optimal.

Secara teori, jika individu pada rentang usia produktif, maka akan mempunyai kapasitas yang optimal. Hasil penelitian juga menunjukkan walaupun variabel usia berhubungan dengan perilaku caring perawat di Ruang rawat Inap Kelas III RSD Balung namun dalam katagori sangat rendah (pvalue= 0,$058 ; \alpha=0,05 ; \mathrm{r}=0,333$ ). Artinya bahwa antara yang usianya muda dan yang usianya lebih tua cenderung tidak ada perbedaan. Hal ini disebabkan oleh karena seluruh responden dalam rentang usia produktif. Sehingga mempunyai kapasistas dalam berperilaku caring yang tidak jauh berbeda. Data ini menunjukkan bukti positifnya jika mempunyai perawat dengan usia produktif.

Kenyataan di atas sedikit berbeda dengan pendapat Robbins (2008) yang menyebutkan bahwa umur juga dapat mempengaruhi kinerja jika dilihat dalam sejumlah hal. Namun biasanya pekerja yang usianya lebih tua mempunyai fleksibilitas yang kurang dan gagap teknologi.

d. Jenis Kelamin

Hasil penelitian menunjukkan bahwa jenis kelamin perawat tidak berhubungan dengan perilaku caring perawat di Ruang rawat Inap Kelas III RSD Balung (pvalue $=0,968 ; \alpha=0,05 ; r=0,007$ ). Kenyataan ini menunjukkan bahwa perawat laki-laki dan perempuan tidak ada bedanya dalam berperilaku caring selama memberikan pelayanan keperawatan. Berdasarkan kodrat perempuan yang dibawa sejak lahir, secara logika seharusnya ada perbedaan mereka dalam memberikan pelayanan. Karena perempuan mempunyai mother instinct yang seharusnya lebih baik dalam berperilaku caring dan mempunyai kapasitas kerja yang lebih baik.

Berpikir secara positif, data yang diperoleh adalah baik jika antara laki-laki dan perempuan sama-sama mempunyai perilaku caring yang baik, tetapi negatifnya adalah jika sama-sama perilaku caringnya tidak baik. Penelitian Hanan (2009) mendapatkan hasil yang berbeda, yaitu jenis kelamin memiliki hubungan dengan kinerja perawat. Yang hasilnya perawat perempuan mempunyai kinerja yang lebih baik bila dibandingkan yang laki-laki.

\section{KESIMPULAN}

Kapasitas perawat dalam memberikan pelayanan keperawatan sangatlah dibutuhkan. Variabel yang berpengaruh secara keseluruhan terhadap variabel perilaku caring adalah variabel tingkat pendidikan. Perawat dalam berperilaku 
caring kepada setiap pasien yang dirawatnya harus dilakukan tanpa memandang suku, bangsa, ras, dan agama.

\section{DAFTAR PUSTAKA}

Asmuji, A., Faridah, F., Handayani, L.T. (2018) Implementation of discharge planning in hospital inpatient room by nurses. Jurnal Ners. Vol. 13 No 1 April 2018. P.106-113. http://dx.doi.org/10.20473/jn.v13i1.5942

Asmuji (2016). Manajemen keperawatan: konsep \& aplikasi. Cetakan III. Yogyakarta: Ar-Ruzz Media.

Chusnawiyah (2015). Hubungan beban kerja dengan perilaku caring perawat pada pasien di Ruang Rawat Inap Kelas 3 RSD Balung. Skripsi. Universitas Muhammadiyah Jember.

Elia, K. P., Josephus, J., Tucunan, A. T. (2016). Hubungan antara kelelahan kerja dan masa kerja dengan produktivitas kerja pada tenaga kerja bongkar muat di Pelabuhan Bitung tahun 2015. PHARMACON Jurnal Ilmiah Farmasi UNSRAT Vol. 5 No. 2. ISSN 2302 - 2493 hal 107-113

Faizin, A., Winarsih (2008). Hubungan tingkat pendidikan dan lama kerja perawat dengan kinerja perawat di RSU Pandan Arang Kabupaten Boyolali. Berita Ilmu Keperawatan ISSN 1979-2697, Vol . 1 No.3, September 2008 : 137142

Grossmann, M. (1999). The human capital model of the demand for health. Cambridge: National Bureau of Economic Research.

Hanan, A.A. (2009). Factors affecting performance of hospital nurse in Riyadh region, Saudi Arabia. International Journal Of Health Care Quality Assurance

Kanestren, D. R. (2009). Analisis hubungan karakteristik individu dan lingkungan kerja dengan kinerja perawat di unit rawat inap RS Pertamina Jaya. Tesis Fakultas Kesehatan Masyarakat Universitas Indonesia Jakarta

Nursalam, 2009. Manajemen keperawatan: aplikasi dalam praktik keperawatan profesional. Edisi 2. Jakarta: Salemba Medika.

Pandaptan, E . (2013). Hubungan antara pendidikan, upah, masa kerja dan usia terhadap produktifitas kerja di PT Gandum Malang. 
Prompahakul, C., Nilmanat, K., Kongsuwan, W. (2011). Nurses' caring behavior for dying patients in Southern Thailand. Nurse Media Jounal of Nursing, 1(2), 147-158.

Robbins, S.P. (2008). Perilaku organisasi. Edisi 12. Jakarta: Salemba Empat

Siangian, S. (2016). Manajemen sumber daya manusia usia. Jakarta : Bumi Aksara

Suarli, S., Bahtiar, Y. (2010). Manajemen keperawatan dengan pendekatan praktis. Jakarta: Penerbit Erlangga.

Sunyoto, D. (2015). Manajemen dan Pengembangan sumber daya manusia. Yogyakarta: CAPS

Watson, J. (2007). Watson theory of human caring and subjective living experiences: carative factors/caritas processes as a disciplinary guide to the professional nursing practice. Texto Contexto Enferm, Florianópolis, 16 (1), $129-35$. 